\title{
In silico methods in stability testing of Hydrocortisone, powder for injections: Multiple regression analysis versus dynamic neural network
}

\author{
Ljiljana N. Solomun ${ }^{1}$, Svetlana R. Ibrićc ${ }^{2}$ Vjera M. Pejanović ${ }^{1}$, Jelena D. Đuriš ${ }^{2}$, Jelena M. Jocković ${ }^{2}$, \\ Predrag D. Stankovic ${ }^{3}$, Zorica B. Vujić ${ }^{2}$ \\ ${ }^{1}$ Hemofarm A.D., Vršac, Serbia \\ ${ }^{2}$ University of Belgrade, Faculty of Pharmacy, Belgrade, Serbia \\ ${ }^{3}$ Institute of Otorhinolaryngology, Clinical Center of Serbia, Belgrade, Serbia
}

\begin{abstract}
This article presents the possibility of using of multiple regression analysis (MRA) and dynamic neural network (DNN) for prediction of stability of Hydrocortisone $100 \mathrm{mg}$ (in a form of hydrocortisone sodium succinate) freeze-dried powder for injection packed into a dual chamber container. Degradation products of hydrocortisone sodium succinate - free hydrocortisone and related substances (impurities A, B, C, D and E; unspecified impurities and total impurities) - were followed during stress and formal stability studies. All data obtained during stability studies were used for in silico modeling; multiple regression models and dynamic neural networks as well, in order to compare predicted and observed results. High values of coefficient of determination (0.95-0.99) were gained using MRA and DNN, so both methods are powerful tools for in silico stability studies, but superiority of DNN over mathematical modeling of degradation was also confirmed.
\end{abstract}

Keywords: hydrocortisone; stability; multiple regression analysis; dynamic neural network.

SCIENTIFIC PAPER

UDC 615.35.07:661.12

Hem. Ind. 66 (5) 647-657 (2012)

doi: 10.2298/HEMIND120207023S

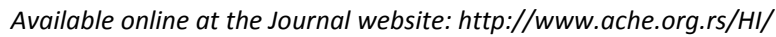

Hydrocortisone $(\mathrm{HC})$, molecular weight 362.465 , is a synthetic corticosteroid drug, (Figure 1) belonging to the group of corticosteroids, which are hydroxyl compounds (alcohols). They are relatively insoluble in water, and the sodium salt of the phosphate or succinate ester is generally used to provide water-soluble forms. Hydrocortisone hydrogen succinate (HC 21-HS) is $11 \beta$, 17-dihydroxy-3,20-dioxopregn-4-en-21-yl hydrogen butanedioate (Figure 1) and it is usually used as active pharmaceutical ingredient.

$\mathrm{HC}$, like all corticosteroids, is an organic compound composed of a specifically condensed tetracyclic structure - a steroid structure and substituents. Considering the chemical structure of this compound, it has been concluded that the most frequent reactions occur at the lateral dihydroxyacetone chain, as well as the transesterifications between the positions C17 and C21.

Görőg has described the process of intramolecular oxidoreduction of lateral dihydroxyacetone chain under the action of oxygen [1], as well as the sensitivity of acid and base to oxidation, depending on the present groups at C21 [2]. As early as in 1961, Herzog et al. [3] explained the changes occurring at $\mathrm{C} 17$ atom, whereby a small polar compound of enol aldehyde type is built in the process of dehydration. Di Giola et al. [4] have described the role of hydroxyl groups in the position C17 and C21 in the course of this reaction. The same associates have concluded that this substance of enol<smiles>C[C@]1(C(=O)CO)CC[C@@H]2[C@@H]3CCC4=CC(=O)CC[C@]4(C)[C@H]3CC[C@]21C</smiles><smiles>C[C@]12CCC(=O)C=C1CC[C@@H]1[C@@H]2[C@H](O)C[C@]2(C)[C@@H]1CC[C@@]2(O)C(=O)COC(=O)CCC(=O)O</smiles>

Figure 1. Structural formulae of Hydrocortisone (HC) and Hydrocortisone-21-hydrogen succinate (HC 21-HS).

Correspondence: Lj. Solomun, Hemofarm a.d., Sektor istraživanja i razvoja, Beogradski put bb, 26300 Vršac, Serbia.

E-mail: Ljiljana.solomun@hemofarm.com

Paper received: 7 February, 2012

Paper accepted: 8 March, 2012 aldehyde type is synthesized as the mixture of $E$ and $Z$ isomers.

HC and HC 21-HS are official in Ph. Eur. $7^{\text {th }}$ (2011) [5], which presents impurities of HC and HC 21-HS. Specified impurities of HC 21-HS are free HC and Hydrocor- 
tisone acetate. Hydrocortisone acetate is a by-product that originates from synthesis and is not consider as degradation product.

$\mathrm{HC}$ and its salts can be processed into different pharmaceutical dosage forms but they are very unstable substances, especially in the presence of moisture. So, for their parenteral administration freezedried pharmaceutical form must be used. A problem associated with this type of injection is the storage of the medications (powder and solution for reconstitution) that should be administered as separate component parts and mixed prior to injection. Therefore, dual chamber vials have been developed to facilitate the storage and mixing of such two-component medications. This container closure system consists of a glass vial with two chambers separated by an intermediate rubber closure and an upper closure on the top. The specific feature of this type of the products is that both the lyophilized active ingredient (in the lower chamber) and the solution for reconstitution (in the upper chamber) are in the same vial (Figure 2).

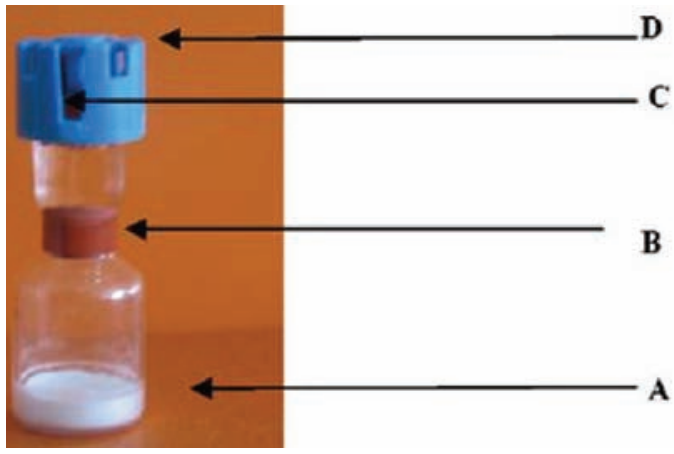

Figure 2. Container closure system: $A$-dual chamber vial; $B$-intermediate closure; $C$ - upper closure; $D$-plastic cap (plastic activator).

The goal of this work was to follow the chemical stabilities of HC $100 \mathrm{mg}$ freeze dried power packaged in dual chamber vial, as a specific container closure system and to evaluate the possibility of using in silico method for prediction stability (multiple regression analysis and dynamic neural network).

\section{Multiple regression analysis}

Regression analysis is the branch of statistics that deals with the relationship (known as the regression function) between one variable $y$ (dependent variable) and several others $x_{i}$ (independent variables). The regression function also involves a set of unknown parameters $b_{i}$. If a regression function is linear in the parameters $b_{i}$, it is known as a linear regression model. Furthermore, if there is more than one independent variable, it is called a multiple linear model.

The general formula for multiple linear models is:

$y_{j}=b_{0}+b_{1} x_{1}+b_{2} x_{2}+\ldots+b_{p} x_{p}, j=1,2, \ldots, n$ with parameters defined as follows: $p$ - number of independent variables; $n$ - number of observations; $y-$ dependent variables (predicted by a regression model); $x_{i}, i=1,2, \ldots, p-$ independent variables (predictors); $b_{i}$ $i=1,2, \ldots, p-$ regression coefficients; $b_{0}-$ intercept (constant).

The main objective of multiple linear regression analysis is to get the best set of parameters $b_{i}$, so that the model predicts experimental values of the dependent variable as accurately as possible (meaning that calculated values $y_{j}$ should be close to values $y_{j}{ }^{*}, j=$ $=1,2, \ldots, n$, obtained by experiment) [6].

\section{Dynamic neural networks (DNNs)}

Dynamic neural networks (DNNs) are artificial neural networks used for the analysis of time series problems. Distinctions of DNNs are multiple presentations of inputs to the neural network allowing for the time dependent integration of inputs and outputs. Past information is used for the prediction of current and future states of the analyzed system. The incorporation of time in the neural networks allows for the nonlinear process to be modelled more precisely with respect to static neural networks. Feedback of the signal is usually performed in the hidden layers of the network. A dynamic neural network has the following characteristics: a high number of the degrees of freedom, i.e., possible connections between neurons, nonlinearity and the ability for dissipation [7]. Biological neurons also express dynamic behavior - apart from performing nonlinear operations they are capable of some other dynamic processes such as time delays, signal feedback and limit cycles [8]. Dynamic networks reportedly used for time series analysis are: memory neuron networks, dynamic neural unit, feedback networks and others [9].

A dynamic network stores long term memory structure in its feedback (recurrent) and regular connections whose weights are adjusted during training [10]. The most prominent characteristics of a memory in neural network are its depth and resolution [11]. DNNs are also referred to as recurrent neural networks. If a network is fully recurrent, then every neuron receives inputs from every other neuron in the network. These networks are not arranged in the layers and still have not been widely employed due to their complexity.

Dynamic neural networks have been employed as an alternative to the model-based approach for the prediction of drug dissolution profiles. The Elman recurrent network has been used to predict the dissolution profiles of a matrix controlled release theophylline pellet preparation [12]. Superiority of dynamic neural networks over static neural networks in modeling of time dependent drug dissolution from hydrophilic polyethylene oxide matrices has been demonstrated [13].

Up to now there has been only one assessment of the possible usage of static neural networks to predict 
the chemical degradation of drugs in stability studies [14]. Neural network modeling based on a back-propagation supervised learning algorithm has been employed to study the physical stability of lipophilic emulsions [15]. The generalized regression neural network model has been developed to assess the crystal purity of mebendazole raw material and to establish its physical stability in a suspension formulation [16]. The stability of the pellets and those of compressed tablets has been evaluated for degradation products under an accelerated stability protocol [17]. The data were analyzed using a static multilayer perceptron neural network and the only qualitative conclusions about the chemical degradation of the active substance could be withdrawn. The combined usage of the back-propagation neural network and a genetic algorithm has been utilized to design organic molecules presenting a specific biodegradability [18]. Genetic algorithms were introduced by Holland [19], mimicking nature's evolutionary method of adapting to a changing environment. They are stochastic optimization methods and provide powerful means to perform directed random searches in a problem space [20]. Genetic algorithms basically represent the population of the candidate solutions to the problem and if no optimum solution is found, a further generation of possible solutions is produced by selecting those solutions judged by some fitness criteria [21].

In the present study, the feasibility of dynamic neural networks to predict the extent of drug degradation is demonstrated. The dynamic treatment of data is possible since the degradation of substances is a time dependent process. Genetic algorithms are proposed as simple yet powerful optimization tools for the selection of an adequate dynamic network topology. The objective of the study is to propose the utilization of dynamic neural networks as in silico tools for the prediction of the degree of drug degradation.

\section{EXPERIMENTAL}

\section{Design of the stability study}

Stability testing is required for predicting the behavior of the medicines during the time. Stability studies were designed through stress and formal stability testing.

Stress stability testing is usually performed in order to define the degradation profile and the kinetics of degradation of active substance and to define the influence of different factors such as temperature, humidity, light etc., on the process of the degradation. In this work, stress studies were performed in order to collect results that could be used for statistical calculation. During this phase, samples were treated under the conditions defined in Table 1.
Table 1. Storage conditions and testing frequencies for stress stability testing; +: testing point at which the sample will be tested; -: testing point at which the sample won't be tested

\begin{tabular}{lcccccccccc}
\hline \multirow{2}{*}{ Storage conditions, ${ }^{\circ} \mathrm{C}$} & \multicolumn{8}{c}{ Testing time points, days } \\
\cline { 2 - 8 } & 7 & 14 & 21 & 28 & 42 & 60 & 90 & 180 \\
\hline 40 & - & - & - & + & - & + & + & - \\
50 & + & + & + & + & + & + & + & + \\
60 & + & + & + & + & + & + & + & + \\
\hline
\end{tabular}

Generally speaking, formal stability testing has to be performed in accordance with relevant guidelines (ICH Q1A(R2), Guideline on Stability Testing: Stability Testing of Existing Active Substances and Related Finished Products, ICH Q1B [22-24] in order to establish or confirm the retest period of a drug substance or the shelf life of a drug product. Formal stability testing includes long-term and accelerated (and intermediate) studies. In this study, formal stability testing was performed in order to get results that could be used to confirm predicted values obtained with mathematical methods. Storage conditions and testing frequencies for formal stability testing are presented in Table 2.

Table 2. Storage conditions and testing frequencies for formal stability testing

\begin{tabular}{lcc}
\hline Storage Conditions & $\begin{array}{c}\text { Testing time points, } \\
\text { months }\end{array}$ \\
\hline Accelerated & $40 \pm 2{ }^{\circ} \mathrm{C} / 75 \pm 5 \% \mathrm{RH}$ & $0,1,2,3$ and 6 \\
Intermediate & $30 \pm 2{ }^{\circ} \mathrm{C} / 65 \pm 5 \% \mathrm{RH}$ & $0,3,6,9$ and 12 \\
Long-term & $25 \pm 2{ }^{\circ} \mathrm{C} / 60 \pm 5 \% \mathrm{RH}$ & $0,3,6,9,12,18$ and 24 \\
\hline
\end{tabular}

Some other stress testing (such as photostability testing) or formal (in use stability testing) tests were performed as well, but these results were not the scope of this article.

During the study, the vials were kept in upright, as well as, in horizontal position. Since there was no difference, herein will be presented only results from samples stored in horizontal position.

For determination of the analytes of interest validated high performance liquid chromatography (HPLC) methods were used.

\section{Materials}

This work was done on Hydrocortisone $100 \mathrm{mg}$ powder for injections, in the form of freeze-dried product in dual chamber vial. It is manufactured by Hemofarm, Vršac, Serbia. The solution for reconstitution is water for injection/ $0.9 \%$ benzyl alcohol. Two milliliters of reconstituted product contains hydrocortisone sodium succinate ( $\mathrm{HCNaS}$ ) equivalent to $100 \mathrm{mg} \mathrm{HC}$.

All samples were conditioned according to the requirements of the International Conference on Harmonization Standards for Stability (Q1A) and Photostability 
(Q1B). The following chambers were used: Weiss 2000, Weiss Gallenkamp, Weiss 600, Weiss Gallenkamp, Sanyo PSC 062, Sanyo Gallenkamp (Great Britain) and Weiss Umwelttechnik 140, Weiss Umwelttechnik, Germany.

The solvents used were: $n$-butyl chloride (Merck, Germany), tetrahydrofuran (Sigma-Aldrich, Germany) methanol (Merck, Germany), glacial acetic acid (SigmaAldrich, Germany), chloroform (Merck, Germany) and ortophosphoric acid (Merck, Germany) were of a grade suitable for high-performance liquid chromatography (HPLC) analysis. HC 21-HS (Aventis Pharma, France), HC and fluorometholone reference standards (RS) were obtained commercially. The reference standards were used without further purification.

\section{Analytical methods}

\section{HPLC method for free HC determination}

Analytical procedure for the free $\mathrm{HC}$ determination was in accordance with USP 32 [25]. The concentration of free $\mathrm{HC}$ is separately expressed, as it is an important degradation product. The analyses were performed on an Agilent Technology 1100 Series HPLC system equipped with $254 \mathrm{~nm}$ detector and column of porous silica particles packing (L3). The flow rate was $1.0 \mathrm{ml} / \mathrm{min}$. Mobile phase was prepared by mixing $n$-butyl chloride, tetrahydrofuran, methanol and glacial acetic acid (95:7:3:3; v/v/v).

Internal standard solution of concentration $3 \mathrm{mg} / \mathrm{ml}$ was obtained by dissolving the required amount of fluorometholone (RS) in tetrahydrofuran.

HC solution. About $7.5 \mathrm{mg}$ of HC RS was accurately weighed, transferred to a $25-\mathrm{ml}$ volumetric flask and diluted with solvent to $25 \mathrm{ml}$.

Solvent. $3 \%$ glacial acetic acid in chloroform.

Standard solution. About $32.5 \mathrm{mg}$ of HC 21-HS RS was weighed accurately and transferred to a $50-\mathrm{ml}$ volumetric flask. $5 \mathrm{ml}$ of internal standard solution and $5 \mathrm{ml}$ of HC 21-HS solution were added. Solvent was added up to $50 \mathrm{ml}$.

Test solution. The tested product was reconstituted according to the manufacturer's directions. Aliquots of 10 vials were collected and $1.0 \mathrm{ml}$ of this solution was transferred to a volumetric flask of $100 \mathrm{ml}$. Internal standard solution was added $(10 \mathrm{ml})$ and dissolved with solvent up to the mark. After 5 minute shaking, layers were separated and upper one was discarded. The injection volume was $10 \mu \mathrm{l}$ of each sample.

\section{HPLC method for determination of related substances}

Analytical procedure for the determination of the related substances was in accordance with internal HPLC isocratic method. The apparatus was Agilent 1100 Series, with a variable wavelength UV-Vis detector. Separation was performed on a Column $\mathrm{C}_{18}(250 \mathrm{~mm} \times 4.6$ $\mathrm{mm}, 5 \mu \mathrm{m})$, and the flow rate was $1.0 \mathrm{ml} / \mathrm{min}$. The mobile phase was prepared by combining acetonitrile, pu- rified water and ortophosphoric acid (33:60:1, v/v/v) and diluted up to $1000 \mathrm{ml}$ with purified water.

Test solution. Reconstituted solutions prepared from the contents of 10 vials of $\mathrm{HCNaS}$ for injection were mixed, $1.0 \mathrm{ml}$ was transferred to $50-\mathrm{ml}$ volumetric flask and diluted with mobile phase up to $20 \mathrm{ml}$. Concentration of solution is $0.1 \% \mathrm{w} / \mathrm{v}$.

Standard solution. $1 \mathrm{ml}$ of test solution was transferred to a 100-ml volumetric flask and diluted with mobile phase. One $\mathrm{ml}$ of this solution was diluted with mobile phase to $10 \mathrm{ml}$. Concentration of standard solution was $0.0001 \% \mathrm{w} / \mathrm{v}$.

The injection volume was $10 \mu \mathrm{l}$ of each sample.

\section{Multiple regression analysis}

Multiple regression analysis (Eq. (1)) was applied. The responses were: free $\mathrm{HC}$, impurities $\mathrm{A}, \mathrm{B}, \mathrm{C}, \mathrm{D}$ and $\mathrm{E}$ which were defined as degradation products due to the increasing concentration during the study; unspecified impurities and total amount of impurities. Predictors (independent variables) were: time (months), temperature $\left({ }^{\circ} \mathrm{C}\right)$ and expressions of type time ${ }^{m} \times$ temperature $^{n}$ with $m, n=0,1,2 \ldots$ Regression models were obtained in two steps.

Step 1. A polynomial of degree 10 on time and temperature was fitted to each of the responses. The fit quality was measured by the coefficient of determination, $R^{2}$.

Step 2. Models obtained in step 2 were improved by removing predictors (terms in the model) that are not statistically significant. This was done by performing a stepwise regression (removing a term that is least statistically significant or adding a term that is most significant in each step, until one obtains an acceptable model).

Expected levels of fit of all models were estimated by means of leave-one-out cross-validation technique. For each of the responses, one of the observations was removed from the sample (validation data), and the model was fitted to the rest of the sample (training data). This is repeated such that each observation is used once as validation data. Finally, as a measure of fit, coefficient of determination was computed. All calculations in this work were performed in MATLAB statistics toolbox.

\section{Dynamic neural network}

Commercially available Peltarion ${ }^{\circledR}$ software was used on a personal computer for designing the dynamic neural network. The topology of a DNN consists of blocks, information processing elements that are connected with links. The links of hidden layer neurons are configured to have a memory of certain order, allowing for the input signal to be delayed for a predetermined number of steps. A pre-designed, built-in partial topology from the software has been used to construct an 
adaptive system. The Recurrent One Layer dynamic network used in the study is represented in Figure 3. Data sources provide inputs and outputs to the network.

The inputs presented to the network were temperature and time whereas outputs were percent of free $H C$, impurities $A, B, C, D$ and $E$; unspecified impurities and the total amount of impurities. The network was presented with the data obtained from stress stability protocols carried out at temperatures of $60,50,40^{\circ} \mathrm{C}$ and from $30^{\circ} \mathrm{C}$, which is part of formal stability study. The data was divided on training and validation set. The ability of the network to predict the degree of degradation at $25{ }^{\circ} \mathrm{C}$ was evaluated in order to test the network. The genetic optimizer algorithm was used in order to improve the network architecture. The progress of errors for both training and validation sets were monitored during training to decide when to stop the training. When there were no more changes in the training error or when the validation error started to diverge, the training was stopped.
Experimentally observed and in silico predicted fractions of free $\mathrm{HC}$, impurities $A, B, C, D$ and $E$; unspecified impurities and total amount of impurities after specific time intervals were compared by the determination of coefficient of correlation $r^{2}$.

\section{RESULTS AND DISCUSSION}

In accordance with USP 32 analytical procedure for the free $\mathrm{HC}$ determination was applied. Chromatograms of standard and test solutions are presented in Figures $4 a$ and $4 b$, respectively. The order of the elution of peaks is: the internal standard peak (fluorometholone), HC 21-HS peak and successive smaller peaks of free $\mathrm{HC}$ and hydrocortisone 17-hydrogen succinate (HC 17-HS).

Chromatogram of related substances - impurities A, $B, C, D$ and $E$, obtained by applying internal, validated HPLC method, is presented in Figure 5.

By following the concentration it was noticed the growing of these five impurities. The increase in concentration of these impurities is proportional to the

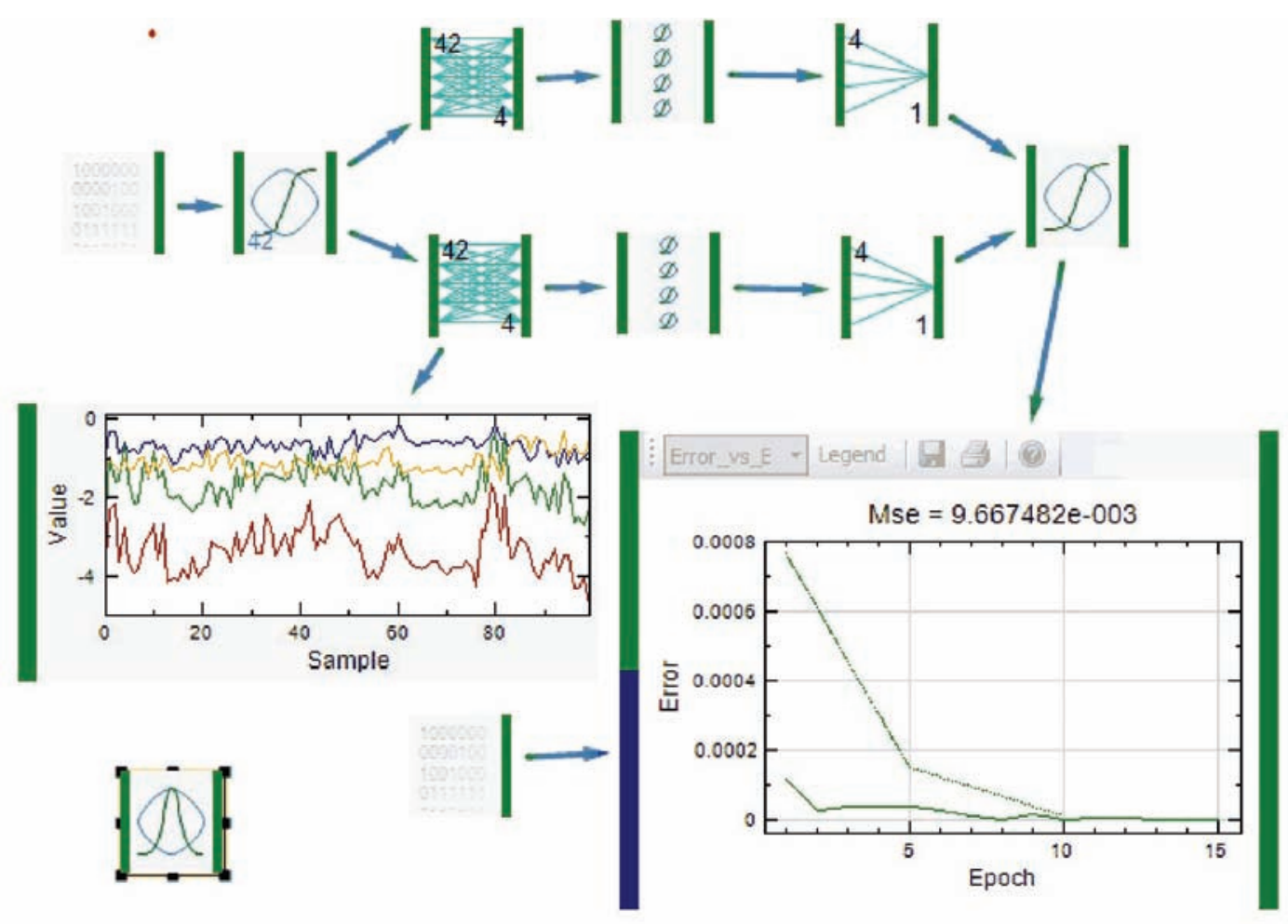

(a)

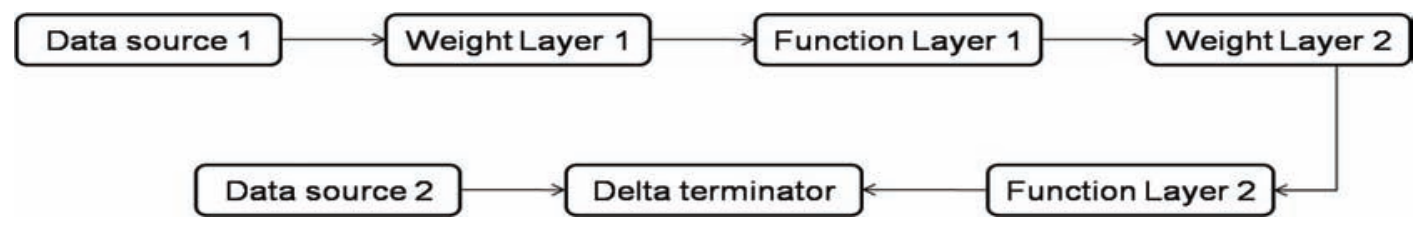

(b)

Figure 3. Representation of dynamic neural network: a) Peltarion ${ }^{\circledR}$ layout, b) schematic representation of the network. 


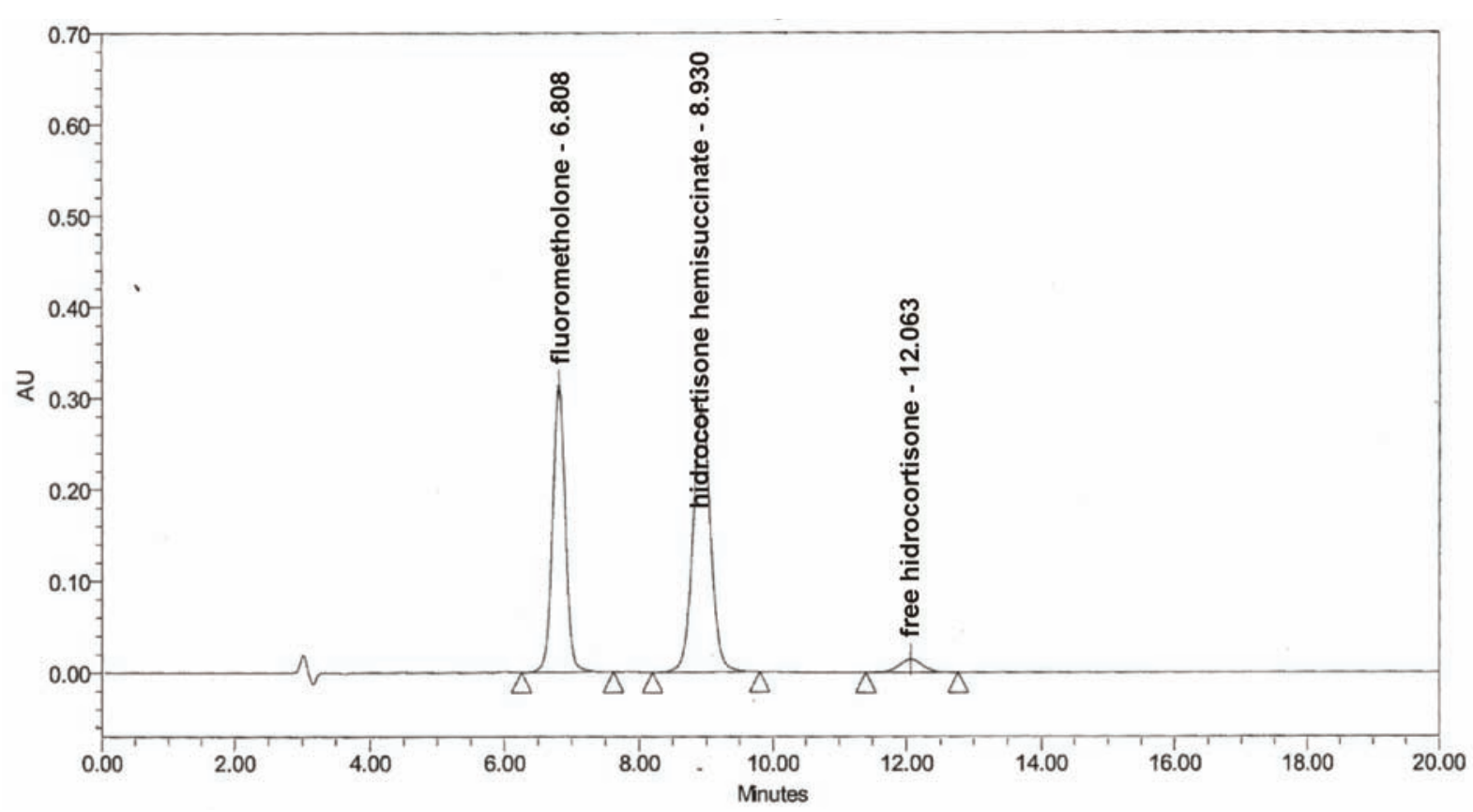

(a)

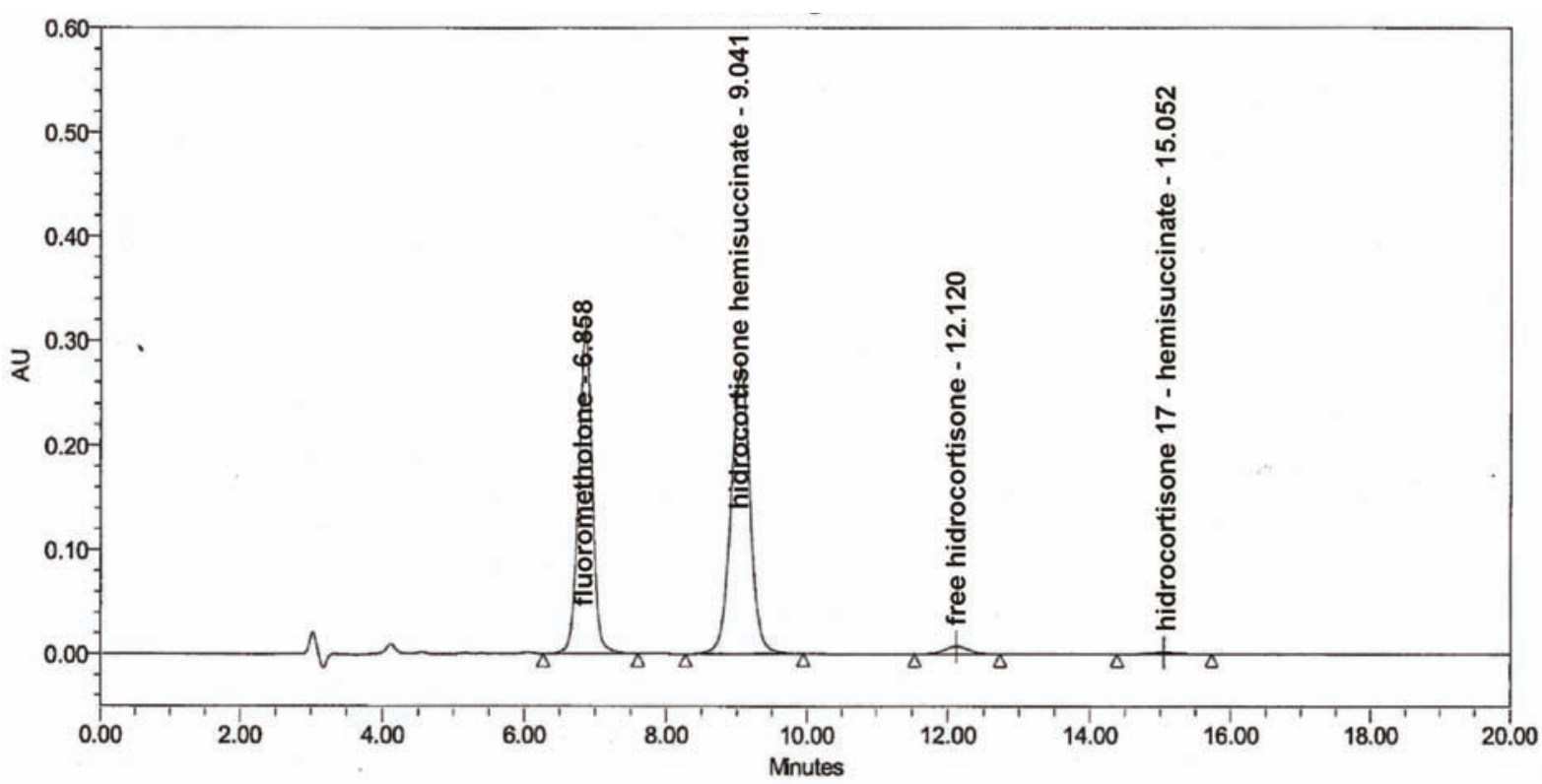

(b)

Figure 4. Chromatograms of standard (a) and test (b) solution.

temperature and time of conditioning, except impurities $C$ (the main product of photodegradation). The order of impurities, from the largest to the smallest concentration was as follow: $B$, then $E, D$ and $A$. The change in concentration of impurity $C$ was the least affected by temperature.

The results of the concentration of free $\mathrm{HC}$ and related substances in stress testing are presented in Tables 3 and 4, respectively.

Those results were used for statistical analysis by applying methods of MRA and DNM. The results of the concentration of free $\mathrm{HC}$ and related substances in for- mal testing are presented in Tables 5 and 6, respectively.

\section{Multiple regression analysis (MRA) modeling}

The results of the multiple regression analysis are presented in Table 7.

High values of coefficient of determination $\left(R^{2}\right.$ from 0.95 to 0.99 ) for impurities $A, B, D$ and $E$ indicate a good correlation between predicted and observed responses. However, despite the fact that a good correlation was observed, the main disadvantage of this method is obvious: separate models for each response as 


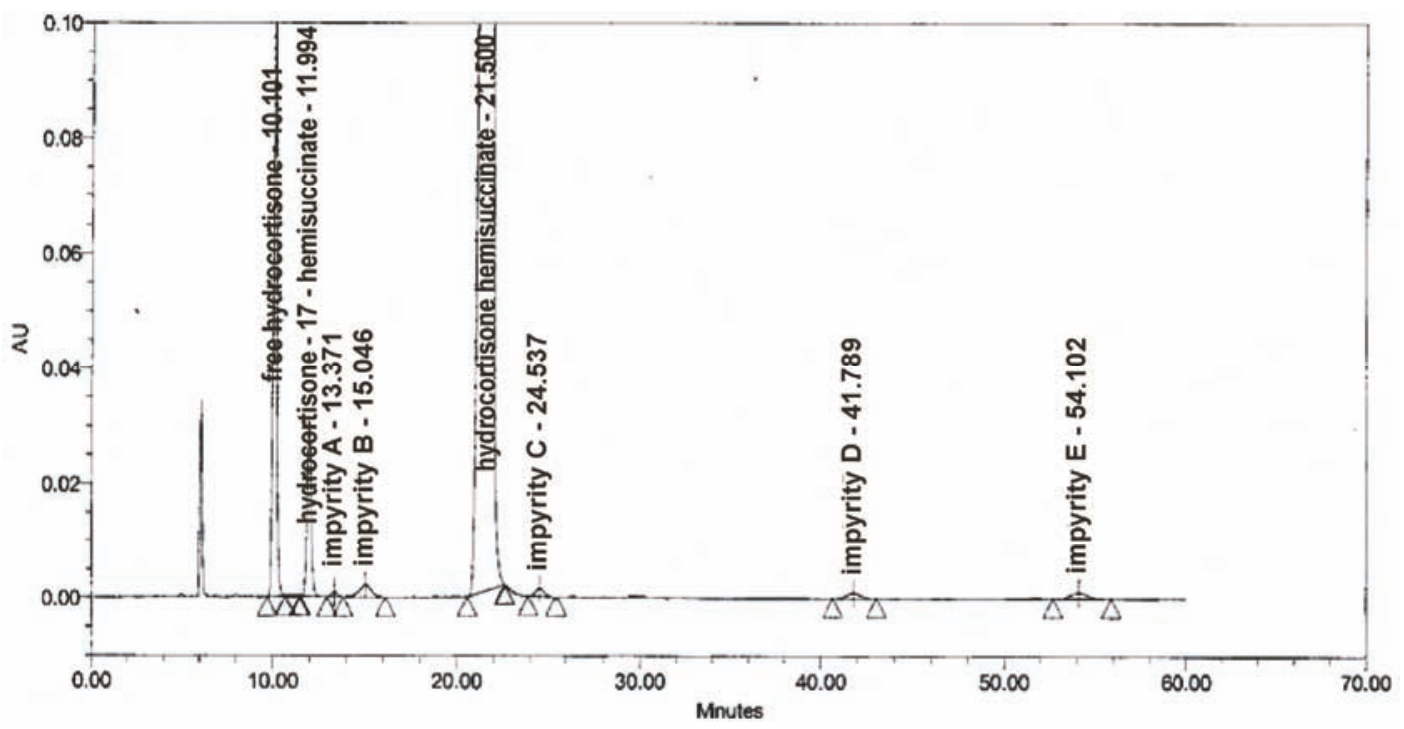

Figure 5. Chromatogram of related substances - impurities $A, B, C, D$ and $E$ are considered as related substances - specified, unidentified impurities.

Table 3. Concentration of free HC expressed as \% of the declared Assay; stress testing; -: testing point at which the sample was not tested, in accordance with plan

\begin{tabular}{lcccccccccc}
\hline \multirow{2}{*}{ Storage condition, ${ }^{\circ} \mathrm{C}$} & \multicolumn{10}{c}{ Testing time points, days } \\
\cline { 2 - 24 } & 0 & 7 & 14 & 21 & 28 & 42 & 60 & 90 & 180 \\
\hline 40 & 2.75 & - & - & - & 2.81 & - & 3.22 & 3.78 & 3.63 \\
50 & 2.75 & 3.11 & 3.25 & 3.27 & 3.52 & 3.66 & 3.81 & 3.95 & 5.01 \\
60 & 2.75 & 3.72 & 3.91 & 4.01 & 4.30 & 4.52 & 4.98 & 6.02 & 10.22 \\
\hline
\end{tabular}

Table 4. Concentrations of related substances (impurities) expressed as \% of the declared Assay; stress testing; -: testing point at which the sample was not tested, in accordance with plan

\begin{tabular}{|c|c|c|c|c|c|c|c|c|c|c|}
\hline \multirow{2}{*}{$t /{ }^{\circ} \mathrm{C}$} & \multirow{2}{*}{ Impurity } & \multicolumn{9}{|c|}{ Testing time points, days } \\
\hline & & 0 & 7 & 14 & 21 & 28 & 42 & 60 & 90 & 180 \\
\hline \multirow[t]{7}{*}{40} & $A$ & 0.03 & - & - & - & 0.03 & - & 0.04 & 0.06 & 0.10 \\
\hline & B & 0.15 & - & - & - & 0.19 & - & 0.26 & 0.32 & 0.40 \\
\hline & C & 0.03 & - & - & - & 0.05 & - & 0.06 & 0.08 & 0.10 \\
\hline & $\mathrm{D}$ & 0.07 & - & - & - & 0.12 & - & 0.15 & 0.18 & 0.22 \\
\hline & $\mathrm{E}$ & 0.11 & - & - & - & 0.16 & - & 0.20 & 0.25 & 0.31 \\
\hline & Single unspecified & 0.02 & - & - & - & 0.02 & - & 0.05 & 0.03 & 0.06 \\
\hline & Total & 0.80 & - & - & - & 0.85 & - & 1.32 & 1.19 & 1.82 \\
\hline \multirow[t]{7}{*}{50} & $A$ & 0.03 & 0.04 & 0.07 & 0.07 & 0.10 & 0.10 & 0.11 & 0.14 & 0.16 \\
\hline & B & 0.15 & 0.23 & 0.34 & 0.34 & 0.38 & 0.41 & 0.48 & 0.58 & 0.77 \\
\hline & C & 0.03 & 0.04 & 0.05 & 0.05 & 0.06 & 0.07 & 0.09 & 0.09 & 0.13 \\
\hline & D & 0.07 & 0.15 & 0.18 & 0.20 & 0.22 & 0.24 & 0.26 & 0.27 & 0.37 \\
\hline & $E$ & 0.11 & 0.22 & 0.26 & 0.30 & 0.33 & 0.36 & 0.38 & 0.42 & 0.59 \\
\hline & Single unspecified & 0.02 & 0.02 & 0.03 & 0.02 & 0.03 & 0.04 & 0.04 & 0.05 & 0.81 \\
\hline & Total & 0.80 & 1.06 & 1.31 & 1.35 & 1.70 & 1.78 & 1.86 & 2.07 & 2.94 \\
\hline \multirow[t]{7}{*}{60} & $A$ & 0.03 & 0.09 & 0.13 & 0.16 & 0.19 & 0.20 & 0.22 & 0.34 & 0.69 \\
\hline & B & 0.15 & 0.37 & 0.57 & 0.51 & 0.67 & 0.68 & 0.72 & 1.37 & 3.99 \\
\hline & C & 0.03 & 0.06 & 0.07 & 0.08 & 0.09 & 0.09 & 0.13 & 0.17 & 0.23 \\
\hline & $\mathrm{D}$ & 0.07 & 0.26 & 0.29 & 0.33 & 0.35 & 0.39 & 0.43 & 0.56 & 1.39 \\
\hline & $\mathrm{E}$ & 0.11 & 0.38 & 0.46 & 0.52 & 0.58 & 0.63 & 0.68 & 0.94 & 2.43 \\
\hline & Single unspecified & 0.02 & 0.04 & 0.04 & 0.06 & 0.07 & 0.08 & 0.09 & 0.11 & 0.49 \\
\hline & Total & 0.80 & 1.62 & 2.09 & 2.11 & 2.44 & 2.68 & 2.89 & 4.32 & 11.1 \\
\hline
\end{tabular}


Table 5. Concentration of free HC expressed as \% of the declared assay; data obtained during formal stability testing; RH - relative humidity; -: testing point at which the sample was not tested, in accordance with plan

\begin{tabular}{|c|c|c|c|c|c|c|c|c|c|}
\hline \multirow{2}{*}{ Storage conditions } & \multicolumn{9}{|c|}{ Testing time points, months } \\
\hline & 0 & 1 & 2 & 3 & 6 & 9 & 12 & 18 & 24 \\
\hline $40^{\circ} \mathrm{C} / 75 \% \mathrm{RH}$ & 2.75 & 2.81 & 3.22 & 3.58 & 3.63 & - & - & - & - \\
\hline $30{ }^{\circ} \mathrm{C} / 65 \% \mathrm{RH}$ & 2.75 & - & - & 3.22 & 2.98 & 3.25 & 3.30 & - & - \\
\hline $25^{\circ} \mathrm{C} / 60 \% \mathrm{RH}$ & 2.75 & - & - & 3.06 & 2.83 & 3.04 & 3.20 & 3.30 & 3.37 \\
\hline
\end{tabular}

Table 6. Concentrations of related substances (impurities) expressed as \% of the declared Assay; data obtained during formal stability testing; $\mathrm{RH}$ - relative humidity; -: testing point at which the sample was not tested, in accordance with plan

\begin{tabular}{|c|c|c|c|c|c|c|c|c|c|c|}
\hline \multirow{2}{*}{$t / \mathrm{RH}$} & \multirow{2}{*}{ Impurity } & \multicolumn{9}{|c|}{ Testing time points, months } \\
\hline & & 0 & 1 & 2 & 3 & 6 & 9 & 12 & 18 & 24 \\
\hline \multirow[t]{7}{*}{$40^{\circ} \mathrm{C} / 75 \% \mathrm{RH}$} & $A$ & 0.03 & 0.03 & 0.04 & 0.06 & 0.10 & - & - & - & - \\
\hline & B & 0.15 & 0.19 & 0.26 & 0.32 & 0.40 & - & - & - & - \\
\hline & $\mathrm{C}$ & 0.03 & 0.05 & 0.06 & 0.08 & 0.10 & - & - & - & - \\
\hline & $\mathrm{D}$ & 0.07 & 0.12 & 0.15 & 0.18 & 0.22 & - & - & - & - \\
\hline & $E$ & 0.11 & 0.16 & 0.20 & 0.25 & 0.31 & - & - & - & - \\
\hline & Single unspecified & 0.02 & 0.02 & 0.05 & 0.03 & 0.06 & - & - & - & - \\
\hline & Total & 0.80 & 0.85 & 1.32 & 1.19 & 1.82 & - & - & - & - \\
\hline \multirow[t]{7}{*}{$30{ }^{\circ} \mathrm{C} / 65 \% \mathrm{RH}$} & $A$ & 0.03 & - & - & 0.02 & 0.05 & 0.04 & 0.06 & - & - \\
\hline & B & 0.15 & - & - & 0.21 & 0.24 & 0.26 & 0.30 & - & - \\
\hline & $\mathrm{C}$ & 0.03 & - & - & 0.03 & 0.09 & 0.04 & 0.04 & - & - \\
\hline & $\mathrm{D}$ & 0.07 & - & - & 0.08 & 0.11 & 0.14 & 0.16 & - & - \\
\hline & $E$ & 0.11 & - & - & 0.14 & 0.19 & 0.19 & 0.23 & - & - \\
\hline & Single unspecified & 0.02 & - & - & 0.02 & 0.03 & 0.03 & 0.02 & - & - \\
\hline & Total & 0.80 & - & - & 0.86 & 1.16 & 1.31 & 1.48 & - & - \\
\hline \multirow[t]{7}{*}{$25^{\circ} \mathrm{C} / 60 \% \mathrm{RH}$} & $A$ & 0.03 & - & - & 0.02 & 0.04 & 0.05 & 0.04 & 0.05 & 0.07 \\
\hline & B & 0.15 & - & - & 0.21 & 0.24 & 0.25 & 0.29 & 0.31 & 0.36 \\
\hline & $\mathrm{C}$ & 0.03 & - & - & 0.04 & 0.08 & 0.06 & 0.07 & 0.08 & 0.06 \\
\hline & $\mathrm{D}$ & 0.07 & - & - & 0.09 & 0.10 & 0.12 & 0.16 & 0.18 & 0.20 \\
\hline & $E$ & 0.11 & - & - & 0.12 & 0.16 & 0.19 & 0.23 & 0.26 & 0.29 \\
\hline & Single unspecified & 0.02 & - & - & 0.02 & 0.02 & 0.03 & 0.03 & 0.03 & 0.04 \\
\hline & Total & 0.80 & - & - & 0.92 & 1.13 & 1.39 & 1.56 & 1.51 & 1.65 \\
\hline
\end{tabular}

Table 7. Regression models obtained using multiple regression analysis; $m-$ time (months); $t-t e m p e r a t u r e ~\left({ }^{\circ} \mathrm{C}\right), b_{0}-b_{26}-$ regression coefficients

\begin{tabular}{|c|c|c|}
\hline Response $(y)$ & Model & $R^{2}$ \\
\hline Free HC & $y=b_{0}+b_{1} t+b_{2} m^{2} t^{4}+b_{3} m^{6} t^{8}$ & 0.6556 \\
\hline Impurity A & $y=b_{0}+b_{1} t^{2}+b_{2} m t^{6}+b_{3} m^{2} t^{9}+b_{4} m^{2} t^{10}+b_{5} m^{3} t^{10}+b_{6} m^{10}$ & 0.9911 \\
\hline Impurity B & $y=b_{0}+b_{1} t^{3}+b_{2} m t^{3}+b_{3} m t^{6}+b_{4} m^{2} t^{5}+b_{5} m^{2} t^{8}+b_{6} m^{3} t^{10}$ & 0.9631 \\
\hline Impurity C & $y=b_{0}+b_{1} t^{5}$ & 0.7361 \\
\hline Impurity D & $y=b_{0}+b_{1} t^{8}+b_{2} t^{9}+b_{3} m t^{3}+b_{4} m t^{6}+b_{5} m^{2} t^{6}+b_{6} m^{3} t^{2}+b_{7} m^{3} t^{8}$ & 0.9781 \\
\hline Impurity E & $y=b_{0}+b_{1} t^{4}+b_{2} m t^{6}+b_{3} m t^{7}+b_{4} m^{2} t^{9}+b_{5} m^{2} t^{10}+b_{6} m^{3} t^{10}$ & 0.9784 \\
\hline Single, unspecified & $y=b_{0}+b_{1} t^{2}+b_{2} m t^{3}+b_{3} m t^{4}+b_{4} m t^{10}$ & 0.7497 \\
\hline Total Impurities & $y=b_{0}+b_{1} t^{3}+b_{2} m t^{8}+b_{3} m^{2}$ & 0.9444 \\
\hline
\end{tabular}

well as ponderous models. With such models it is hard to manipulate in terms of the simultaneous prediction of all impurities in the product (Table 7).

\section{Dynamic neural network (DNN) modeling}

The dynamic network consists of an input layer, one hidden layer and an output layer. From data source 1, the signal goes to the first Weight layer. The first weight layer has 2 inputs and 7 outputs. The number of outputs has been optimized using a Genetic Optimizer algorithm in the training mode of the program. From the first Weight layer, 7 outputs go to the first Function layer that has modified links and a feedback connection to itself. The developed dynamic network is a partially recurrent network since the recurrent connections are sent from the hidden layer back to itself. The recur- 
rence of signals is determined by the order of the link memory. Mandatory memory is added to the recurrent link as well as the interpolation parameter; weight $\mu$. Local feedback is always scaled with $1-\mu$. For each of the 7 outputs there is a separate feedback $\mu_{1}$ to $\mu_{7}$; outputs were optimized using a Genetic Optimizer, making it possible to set up connections that can most adequately predict future states of the system. For simulations used to construct dynamic network the number of populations was 200 and there were 1000 generations and 100 epochs. From the first, recurrent function layer, signal goes to second Weight layer that has 7 inputs and 8 outputs (fractions of $\mathrm{HC}$ and impurities). From the second weight layer signals go to the second function layer. The second Function layer is an ordinary function layer (in comparison to the first function layer). It has 8 inputs and 8 outputs and performs Tanh sigmoid function. The function of the delta terminator is to compare two signals - the first signal comes from the data source 2 and represents real, observed outputs; whereas the second signal comes from the second function layer and represents outputs predicted by the dynamic system. A strong correlation between observed and predicted values of the amount of free HC, impurities A, B, C, D and E; unspecified impurities and a total amount of impurities has been obtained. Experimentally observed values and values predicted by DNN as well as correlation coefficients at specific time intervals are given in Tables 8 and 9.

Correlation of predicted and obtained values after 24 months for all tested parameters is presented in Figure 6.

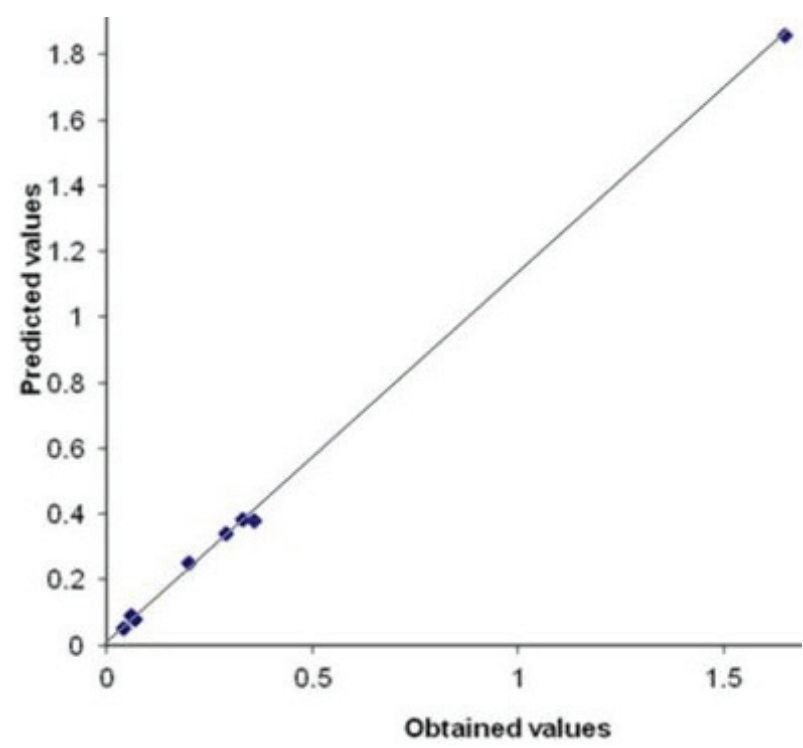

Figure 6. Correlation of experimental and predicted concentrations of $H C$, impurities $A, B, C, D$ and $E$; unspecified impurities and total amount of impurities at $25{ }^{\circ} \mathrm{C}$ after 24 months.

The correlation between observed and predicted values is confirmed by $r^{2}$ ranging from 0.9622 to 0.9910 . The capability of DNN to predict the degree of degradation was confirmed by comparing predicted and experimental data obtained by following degradation at $25{ }^{\circ} \mathrm{C}$ after different time intervals $(3,6,9$ and 24 months).

It is important to emphasize that the ability of the network to accurately predict the degree of degradation does not lessen with the increase of length of

Table 8. Experimentally observed values and values predicted by DNN at specific time intervals; ImpA, ImpB, ImpC, ImpD and ImpE are \% of impurities $A, B, C, D$ and $E$, respectively; unsp is percent of unspecified impurities and tot is percent of the total amount of impurities

\begin{tabular}{llcccccccc}
\hline Time, months & Value & $H C / \%$ & $I m p A$ & $I m p B$ & $I m p C$ & $I m p D$ & $I m p E$ & unsp & tot \\
\hline 3 & Observed & 3.060 & 0.02 & 0.21 & 0.04 & 0.06 & 0.12 & 0.02 & 0.92 \\
& Predicted & 3.020 & 0.02 & 0.05 & 0.03 & 0.04 & 0.08 & 0.03 & 0.72 \\
6 & Observed & 2.830 & 0.04 & 0.24 & 0.08 & 0.10 & 0.16 & 0.02 & 0.13 \\
& Predicted & 3.808 & 0.09 & 0.31 & 0.08 & 0.17 & 0.27 & 0.05 & 1.50 \\
9 & Observed & 3.040 & 0.05 & 0.25 & 0.06 & 0.12 & 0.19 & 0.03 & 1.39 \\
& Predicted & 3.690 & 0.08 & 0.34 & 0.08 & 0.17 & 0.26 & 0.04 & 1.47 \\
12 & Observed & 3.200 & 0.04 & 0.29 & 0.07 & 0.16 & 0.23 & 0.03 & 1.56 \\
& Predicted & 3.590 & 0.06 & 0.36 & 0.09 & 0.17 & 0.25 & 0.04 & 1.47 \\
18 & Observed & 3.300 & 0.05 & 0.31 & 0.08 & 0.18 & 0.26 & 0.03 & 1.51 \\
& Predicted & 3.618 & 0.06 & 0.30 & 0.09 & 0.19 & 0.27 & 0.04 & 1.55 \\
& Observed & 3.300 & 0.07 & 0.36 & 0.06 & 0.20 & 0.29 & 0.04 & 1.65 \\
& Predicted & 3.831 & 0.08 & 0.38 & 0.09 & 0.25 & 0.34 & 0.05 & 1.86 \\
\hline
\end{tabular}

Table 9. Coefficient of correlation of experimental and predicted values for specific time intervals

\begin{tabular}{lcccccc}
\hline Time, months & 3 & 6 & 9 & 12 & 18 & 24 \\
\hline Coefficient of correlation & 0.9797 & 0.9910 & 0.9856 & 0.9622 & 0.9796 & 0.9876 \\
\hline
\end{tabular}


time. This finding supports the usage of dynamic networks for predicting the stability of pharmaceutical products, i.e., shelf life.

\section{CONCLUSION}

It has been demonstrated that dynamic neural networks are powerful tools for in silico stability studies. When compared to the MRA modeling of HC degradation, DNN shows superiority in terms of ease of application and the handling of obtained results.

With MRA models it is hard to manipulate in terms of the simultaneous prediction of all impurities in the product because the fact that every impurity requires its own models. On the other hand, DNN allows to set up connections between observed values and to get one network that can most adequately predict future states of the system. Furthermore, the ability of network to accurately predict the degree of degradation is not affected by the time.

By comparing predicted and experimental data it is confirmed that DNNs can be successfully used to predict the amount of drug degradation during storage, i.e., to predict the shelf life of the drug product.

\section{Acknowledgment}

We gratefully acknowledge the financial support from the Ministry of Education, Science and Technological Development of the Republic of Serbia, grants TR 34031 and TR 34007.

\section{REFERENCES}

[1] S. Gőrőg, G. Szász, Analysis of Steroid Hormone Drugs, Elsevier, Amsterdam, 1978.

[2] S. Gőrőg, Quantitative Analysis of Steroids, Elsevier, Amsterdam, 1983.

[3] M.J. Herzog, H.M. Gentles, H. Marshall, E.B. Hershberg, Weak Acid-catalyzed Rearrangement of the Dihydroxyacetone Side Chain in Steroids, J. Am. Chem. Soc. 83 (1961) 4073-4076.

[4] M.L. Di Giola, A. Leggio, A.L. Pera, A. Liguori, A. Napoli, C. Siciliano, G. Sindona, A facile approach to steroidal 20-hydroxy-17(20)-en-21-aldehydes: important intermedies in the biological 17-dehydroxylation of C-!7 dihydroxyacetone steroids, Tetr. Lett. 42 (2001) 7413-7415.

[5] European Pharmacopoeia 7.0 (2011), Strasbourg: Council of Europe.

[6] L. Aiken, S. West, Multiple Regression: Testing and Interpreting Interactions, Sage Publications, London, 1991.

[7] P. Peretto, J.J. Niez, Long term memory storage capacity of multiconnected neural networks, Biol. Cyber. 54 (1986) 53-63
[8] M.M. Gupta, L. Jin, N. Homma, Static and Dynamic Neural Networks: From Fundamentals to Advanced Theory, Wiley \& Sons, New York, 2003.

[9] A.M. Shaw, F.J. Doyle, J.S. Schwaber, A dynamic neural network approach to nonlinear process modelling, Comput. Chem. Eng. 21 (1997) 371-385.

[10] S. Samarasinghe, Neural Networks for Applied Sciences and Engineering, Auerbach Publications, New York, 2006.

[11] S. Haykin, Neural networks - A Comprehensive Foundation, Prentice-Hall, New Jersey, 1995.

[12] W.Y. Goh, C.P. Lim, K.K. Peh, K. Subari, Application of a Recurrent Neural Network to Prediction of Drug Dissolution Profiles, Neural. Comput. Appl. 10 (2002) 311317.

[13] J. Petrović, S. Ibrić, G. Betz, J. Parojčić, Z. Đurić, Application of dynamic neural networks in the modeling of drug release from polyethylene oxide matrix tablets, Eur. J. Pharm. Sci. 38 (2009) 172-180.

[14] S. Ibrić, M. Jovanović, Z. Đurić, J. Parojčić, Lj. Solomun, B. Lučić, Generalized regression neural networks in prediction of drug stability, J. Pharm. Pharmacol. 59 (2007) 745-750.

[15] M. Gašperlin, L. Tušar, M. Tušar, J. Kristl, J. Šmid-Korbar, Lipophilic semisolid emulsion systems: viscoelastic behavior and prediction of physical stability by neural network modeling, Int. J. Pharm. 168 (1998) 243-254.

[16] S. Agatonovic-Kustrin, B.D. Glass, M. Mangan, J. Smithson, Analyzing the crystal purity of mebendazole raw material and its stability in a suspension formulation, Int. J. Pharm. 361 (2008) 245-250.

[17] M. Türkolu, H. Varol, M. Çelikok, Tableting and stability evaluation of enteric-coated omeprazole pellets, Eur. J. Pharm. Biopharm. 57 (2004) 279-286.

[18] J. Devillers, C. Putavy, Designing biodegradable molecules from the combined use of a backpropagation neural network and a genetic algorithm, Gen. Algor. Mol. Model. 12 (1996) 303-314.

[19] [19] J. Holland, Adaptation in Natural and Artificial System, University of Michigan Press, USA, 1975.

[20] L. Terfloth, J. Gasteiger, Neural networks and genetic algorithms in drug design, Drug Disc.Today 6 (2001) 102108.

[21] R.C. Rowe, R.R. Roberts, Artificial intelligence in pharmaceutical product formulation: neural computing and emerging technologies, Pharm. Sci. Tech. Today 1 (1998) 200-205.

[22] ICH Q1A (R2), Stability Testing of New Drug Substances and Products, ICH Steering Committee, 2003.

[23] Guideline on Stability Testing: Stability Testing of Existing Active Substances and Related Finished Products, The European Medicinal Agency, 2004.

[24] ICH Q1B Stability Testing: Photostability Testing of New Drug Substances and Products, ICH Steering Committee, 1996.

US Pharmacopoeia, $33^{\text {rd }}$ ed., US Pharmacopoeia Convention, Rockville, MD, 2009. 


\section{IZVOD}

\section{IN SILICO METODE U ISPITIVANJU STABILNOSTI HIDROKORTIZONA, LIOFILIZATA ZA INFUZIJU: VIŠESTRUKA REGRESIONA ANALIZA I DINAMIČKE NEURONSKE MREŽE}

Ljiljana N. Solomun ${ }^{1}$, Svetlana R. Ibrić ${ }^{2}$, Vjera M. Pejanović ${ }^{1}$, Jelena D. Đuriš ${ }^{2}$, Jelena M. Jocković ${ }^{2}$, Predrag D. Stankovic ${ }^{3}$, Zorica B. Vujić ${ }^{2}$

${ }^{1}$ Hemofarm A.D., Vršac, Srbija

${ }^{2}$ Univerzitet u Beogradu,Farmaceutski fakultet, Beograd, Srbija

${ }^{3}$ Institut za otorinolaringologiju, Klinički centar Srbije, Beograd, Srbija

\section{(Naučni rad)}

Radi bezbednije, brže i efikasnije parenteralne primene hidrokortizona, široko primenjivanog kortikosteroida, ispitivan je sistem kontaktnog pakovanja u kome su i liofilizat i rastvor za rekonstituciju nalaze u jednoj, dvokomornoj bočici. Ispitivanje je izvedeno na preparatu Hidrokortizon, 100 mg, liofilizat za rastvor za injekcije. Inicijalno postavljeni parametri kvaliteta su provereni prvo kroz studije stres stabilnosti sa posebnim akcentom na promenu koncentracije slobodnog hidrokortizona, odnosno definisanje degradacionog profila ispitivanog proizvoda. Ispitivanje je vršeno pod uslovima povišene temperature $\left(40,50\right.$ i $\left.60^{\circ} \mathrm{C}\right)$ u trajanju od tri, odnosno šest meseci. Rezultati su pokazali da dolazi do porasta koncentracije slobodnog hidrokortizona u funkciji vremena i temperature. Takođe, detekovano je prisustvo pet degradacionih proizvoda. Dobijeni rezultati u toku stres ispitivanja stabilnosti su korišćeni u statističkim proračunima. Potvrda kako definisanog kvaliteta proizvoda, tako i predvidjanja stabilnosti korišćenjem in silico metoda dobijena je kroz ispitivanje stabilnosti metodom formalnog ispitivanja, pod uslovima ubrzanog $\left(40{ }^{\circ} \mathrm{C} / 75 \% \mathrm{RH}\right)$, intermedijernog $\left(30{ }^{\circ} \mathrm{C} / 65 \% \mathrm{RH}\right)$ i dugotrajnog starenja $\left(25{ }^{\circ} \mathrm{C} / 60 \% \mathrm{RH}\right)$. Tokom ispitivanja detektuje se porast koncentracije slobodnog hidrokortizona, ali i srodnih supstanci (nečistoća) koje se javljaju pod uticajem temperature (nečistoće $A, B, D$ i E), odnosno $C$ koja je proizvod fotodegradacije. Ovi degradacioni proizvodi nastaju intramolekulskim premeštanjima. U opisivanju brzine degradacije hidrokortizona, korišćene su metode multiple regresione analize (MRA) i dinamičke neuronske mreže (DNM), a dobijeni rezultati su poređeni sa rezultatima ispitivanja uzorka pod uslovima ubrzanog i dugotrajnog starenja. Primenom MRA dobijene su visoke vrednosti koeficijenta korelacije $\left(R^{2}\right.$ od 0,95 do $0,99)$ osim za slobodni hidrokortizon $(0,65)$, nečistoću $C(0,73)$ i slobodne nespecificirane $(0,74)$, što pokazuje da postoji dobra korelacija između predviđenih i eksperimentalno dobijenih odgovora. Kada je primenjena neuronska mreža tipa RJDM, visoke vrednosti koeficijenta korelacije (od 0,96 do 0,99) pokazuju da je mreža obučena da predvidi stepen degradacije hidrokortizona na $25^{\circ} \mathrm{C}$ u različitim vremenskim intervalima. Dobijeni rezultati pokazuju da se obe in silico metode mogu uspešno koristiti u predviđanju procenta nečistoća i brzine degradacije lekovitih supstanci. Prednost korišćenja neuronskih mreža je što je sa njom moguće istovremeno manipulisati sa svim odgovorima (tj. nečistoćama), tj. vrlo jednostavno, jednom kada je mreža istrenirana, predvideti koncentracije svih nečistoća ispitivanih preparata na bilo kojoj temperaturi i u bilo kom vremenu.
Ključne reči: Hidrokortizon • Stabilnost • Višestruka regresiona analiza • Dinamičke neuronske mreže 